\title{
Education Research (SSEER 2020) \\ Research on Training Talents of Intelligent Logistics in Higher Vocational Colleges Against the Background of New Western Land-Sea Corridor
}

\author{
Ke Wang* \\ School of Business \\ Chongqing Vocational College of Transportation \\ Chongqing 402247, China \\ wangke1979@qq.com
}

\begin{abstract}
This paper analyzes the future demand for intelligent logistics talents against the background of the national development strategy of the new western land-sea corridor, and puts forward the future intelligent logistics enterprise talent needs three main aspects, one is skill type pipe intelligent logistics talents, the second is data management and analysis type intelligent logistics talents, the third is commerce application management intelligent logistics talents, And according to these three kinds of talent needs, the future higher vocational intelligent logistics talent training, education and training reform direction is proposed, is an outstanding new technology traction innovation training mode, the second is enhancing universityenterprise cooperation to optimize curriculum, 3 it is to play to the channel characteristics of talent cultivation characteristics.
\end{abstract}

Keywords-new western land-sea corridor; higher vocational; intelligent logistics; talents training

\section{INTRODUCTION}

With the development of new technology and business model, China's logistics industry is in a critical period from traditional logistics to smart logistics, artificial intelligence, cloud computing, big data, block chain, digital twin technology, quantum technology in-depth application in the field of high and new technology in logistics are constantly changing the operation of the logistics industry and the management pattern, the traditional personnel intensive jobs is to develop in the direction of unmanned, operation mode, management mode and the positions and functions change then there is the demand of change. New western land -sea corridor, which is based on "One Belt And One Road", used rail, air, highway, waterway transport a variety of ways with southeast Asia the main logistics nodes to form trade network, at the same time by Meanwhile, a trade network has been formed with major Logistics nodes in Europe through the Chongqing-XinjiangEurope Railway, the Chengdu-Xinjiang-Europe Railway and the Xi'an -Xinjiang-Europe Railway freight trains, become the organic link "area" of the new international trade channels. Logistics as new western land-sea corridor of the national

Chongqing Vocational College of Transportation science and technology project (CJKJ201902) development strategy important support in the west and the west is directly related to the development of logistics industry in new western land-sea corridor effectiveness of channel development, the future with the in-depth development of logistics in the logistics industry in western wisdom, the wisdom of the adapted to the development of the logistics demand will also be an important problem to solve, this article will new western land-sea corridor in the west as the background delve into how higher vocational colleges logistics professional according to new western land-sea corridor wisdom logistics talent demand characteristics for talent training [1-6].

\section{THE DEMAND CHARACTERISTICS OF INTELLIGENT LOGISTICS TALENTS IN HIGHER VOCATIONAL COLLEGES AGAINST THE BACKGROUND OF NEW WESTERN LAND-SEA CORRIDOR}

According to the national Development and Reform Commission's overall Plan for the new western land-sea corridor, smart logistics will become an important support for the national strategic development of the new western land-sea corridor and a new economic growth point. Against the background of further deepening construction of the national strategy of the new western land-sea corridor, the logistics enterprises of the new western land-sea corridor will complete the transformation and development from traditional logistics to smart logistics enterprises in the next 5 to 10 years. At the same time, the traditional logistics jobs will be gradually replaced by type wisdom logistics jobs, with wisdom logistics for the needs of a large number of new jobs will be caused, such as: intelligent logistics equipment operation and maintenance management, big wisdom logistics data analysis, logistics financial management, cross-border electricity wisdom logistics management, AI digital storage and distribution operation management wisdom logistics new jobs, and these jobs compared with traditional logistics jobs demand for talent is more prominent performance in can understand technology, management, business intelligence applied logistics talents. Over the next five to 10 years, which is based 
on the new western land-sea corridor of logistics enterprises in the wisdom logistics talent gap will become very big, national strategy based on new western land-sea corridor and related logistics analysis of the current situation of the development of logistics enterprises and wisdom in the future the most short of three kinds of intelligent new western land-sea corridor development in western logistics talent: skills pipe wisdom logistics personnel, data management and analysis of logistics personnel, business application management wisdom logistics talents.

\section{A. Skilled Operation and Management of Intelligent Logistics Talent Demand}

Through the investigation of western logistics enterprises in Chongqing, Guiyang, Beihai, Chengdu, Xi 'an, etc., the survey found over the next five to 10 years intelligent logistics facilities will gradually replace the traditional logistics facilities, in particular, some large logistics enterprise logistics facilities of intelligent than to reach more than $90 \%$ from the current $40 \%$, traditional logistics jobs will be replaced by intelligent logistics facilities, such as sorting, distribution, circulation processing traditional personnel intensive jobs will be under the intelligent logistics equipment to replace gradually realize unmanned; But at the same time, we can see as smart logistics equipment to replace the traditional logistics jobs, at the same time also appear with the new position, such as smart logistics equipment cooperative operating post, intelligent logistics equipment operation and maintenance management positions for smart logistics equipment maintenance will operation, good management, to understand the smart skills type pipe position, and at present, most vocational colleges have yet to this aspect of talent cultivation, which makes this type of talent will become one of the most shortage of talent in the future.

\section{B. Data Management and Analytical Intelligent Logistics Talents Need Urgently}

A significant characteristic of intelligent logistics is digitalization, which is often referred to as digital logistics. Through a large number of data analysis, enterprises can accurately control the whole link of logistics to achieve the optimization of logistics management, so as to maximize profits. The logistics enterprises of the new western land-sea corridor have formed a trade network with the major logistics nodes in Southeast Asia through railway, air transport, road and water transport, and at the same time have formed a trade network with the major logistics nodes in Europe through the Chongqing-Xinjiang-Europe Railway, the Chengdu-XinjiangEurope Railway and the Xi'an-Xinjiang-Europe Railway freight trains. Making every day a lot of logistics data, especially cross-border logistics data, because the data is variety, huge amount of data and quick change, internationalization, characteristics of the difference of system, which requires large amounts of data management and analysis type wisdom logistics talents of the data management and analysis, from the data found in the growth of logistics efficiency to maximize economic efficiency of logistics enterprises, especially with the further development of the new western land-sea corridor in the next five years, the demand of talents will be into explosive growth, and at present, most vocational colleges have yet to this aspect of the cultivation of talents, This makes such talents become one of the most needed talents in the future.

\section{Business and Trade Application Management of Human Intelligence Logistics Talent Demand is Urgent}

New western land-sea corridor logistics enterprises by rail, air, highway, waterway transport a variety of ways with southeast Asia main logistics nodes to form trade network, at the same time by Chongqing-Xinjiang-Europe Railway, the Chengdu-Xinjiang-Europe Railway and the Xi'an-XinjiangEurope Railway freight trains and China-Europe trains and major European logistics node form trade networks, become a new international trade channel connecting One Belt And One Road. This makes every day there are a large number of commercial activities need logistics companies to complete, especially international trade logistics, because the international logistics has variety of information, large difference of system environment, general business, high degree of internationalization, etc., which requires a lot of business application management wisdom logistics personnel to manage cross-border logistics activities of the international trade, so as to guarantee smooth logistics operation efficiently in international trade and business, logistics service quality further improve effectively, especially with the further development of the new western land-sea corridor in the next five years, the international logistic growth rate would increase greatly, The demand for talents in this field will explode. However, at present, most of the logistics majors in higher vocational colleges have not set the professional curriculum or formulated the talent training program in this field, which makes such talents become one of the scarcest talents in enterprises in the future.

\section{The Cultivation Method of InTELligent LOGISTICS TALENTS IN HIGHER VOCATIONAL COLLEGES AGAINST THE BACKGROUND OF NEW WESTERN LAND-SEA CORRIDOR}

Based on the analysis of the characteristics of the demand for smart logistics talents against the background of the new western land-sea corridor, and combined with the deficiencies of the current cultivation methods for talents of logistics majors in higher vocational colleges, this paper proposes three cultivation methods for smart logistics talents in higher vocational colleges against the background of the new western land-sea corridor

\section{A. Highlight New Technology Traction Innovation Training Mode}

The core of intelligent logistics is the continuous application of new technology in logistics, so as to change the operation mode, management mode and business mode of the whole logistics industry. Can be thought of as new technology is the core of the whole logistics industry development and operation of traction, the new technology of traction with the development of logistics industry, and the training of logistics personnel in the service of the development of logistics industry, as a result, the new technology is the core of higher vocational logistics personnel training of traction, this requests us in the training of logistics personnel highlight the new 
technology to the traction and traction innovation personnel training mode in the new technology; Integrate the learning, application and development of new technologies into our curriculum, the formulation of talent training programs and practical training; Change the previous training mode of emphasizing management over technology, increase the proportion of new technology in personnel training, and highlight the study and application of new technology, especially the proportion of new technology in practical training. At present, artificial intelligence, big data, block chain, quantum technology, digital twin technology, Internet of things and cloud computing will be the key contents to be integrated into the personnel training of higher vocational logistics majors in the direction of new technology in the future.

\section{B. Strengthen School-enterprise Cooperation to Optimize Curriculum Provision}

Higher vocational talents training goal is to carry the talent they need for enterprise development, enterprise's real demand is the fundamental requirement of higher vocational logistics personnel training, enterprise need what kind of person, what would need to develop talents in higher vocational colleges, and enterprises demand only through effective cooperation between colleges can truly effective real-time transmission to the school, the school can according to enterprise's talents needs to constantly adjust the talent training scheme, optimizing the curriculum in order to adapt to real enterprise demand for talents of different levels of ability; At present, due to various reasons university-enterprise cooperation in research and consulting enterprises, employment cooperation such as simple level, enterprise real dominated the school personnel training and the curriculum model has not yet formed, the enterprise development, talent demand, post Settings, and so on as the basic requirement of higher vocational logistics professional curriculum, make the enterprise post demand directly into the curriculum, to achieve a post a class or more than one duty class curriculum mode, in the process of enterprise development continued demand for post personnel changes in the real-time optimization of higher vocational curriculum truly and talent post one to one correspondence courses, the real-time optimization. At present, smart logistics equipment operation and maintenance management, smart logistics big data analysis, smart logistics financial management and green smart logistics management will be the key contents to be integrated into the curriculum of higher vocational logistics specialty in the future.

\section{Give Full Play to the Characteristics of the Channel to Train Special Talents}

New western land-sea corridor passage, its main task is to further expand trade and business between China and southeast Asian countries, and through multiple logistics hub in railway, highway, water transport, multimodal transport way to complete its logistics activities, and our country and the southeast to the country's commercial activities have focused on fresh, fruits, vegetables, aquatic products such as administration organs of military-run agricultural and mechanical and electrical products, such as light industrial electronics, motorcycle, rubbing matching; Therefore, against the background of the new land-sea corridor in the west, the cultivation of intelligent logistics talents in higher vocational colleges should focus on cold chain logistics, cross-border ecommerce logistics and multimodal transport logistics. The first is to highlight the cultivation of intelligent cold chain logistics equipment operation, maintenance and management talents, smart logistics hub warehousing distribution logistics equipment operation talents and other skills of intelligent logistics management talents; The second is to highlight the cultivation of e-commerce logistics big data analysis talent, smart logistics financial management talent and other data management and analysis smart logistics talent; Third, talents in operation of international business smart logistics management platform, cross-border e-commerce smart logistics operation management and other business application management smart logistics talents.

\section{CONCLUSION}

In this paper, the new western land-sea corridor national development strategy against the background of the future wisdom logistics demand is analyzed, the main table in talent demand, skills type pipe wisdom logistics personnel, data management and analysis model wisdom and commercial application of the logistics personnel management wisdom logistics talents, these three kinds of talented person's demand will be the future logistics enterprise's most pressing wisdom, talent demand is put forward for the three kinds of future pertinence wisdom logistics personnel training needs of traction innovation training mode from outstanding new technology, optimize the curriculum and enhancing universityenterprise cooperation channel characteristic talent training characteristics of talents from three aspects of education reform The research of this paper aims to provide some ideas and methods to promote the training of higher vocational talents under intelligent logistics. Meanwhile, the Suggestions will be further changed with the emergence of new technologies and new business models in the future, which is also the direction of the future research of this paper.

\section{ACKNOWLEDGMENT}

This work was supported by Chongqing Vocational College of Transportation science and technology project (CJKJ201902).

\section{REFERENCES}

[1] Ke Wang. (2019) "Logistics Management Model of Fresh Agricultural Products in the New International Land-Sea Trade Corridor Based on Information Network". Revista de la Facultad de Agronomia de la Universidad del Zulia, 36(4), pp. 1078-1085

[2] Ke Wang, "Research on the application of VR technology in logistics equipment application and management course teaching," ICEIEM. Penang, Malaysia, vol. 2, pp. 77-79, August 2019 [ICEIEM 2019 Penang, Malaysia, pp. 77-79, 2019.

[3] ZHOU Minngjun. (2019) "Pragmatically promote the construction of new land and sea corridors in the west". Guangxi Economy, 31(11), pp. 46-47. (In Chinese).

[4] Ke Wang. (2019) "Study on the Structure of Waste Material Reverse Logistics System Based on Cainiaoyizhan”. Logistics Technology, 38(6) pp. 145-147. (In Chinese) 
[5] DONG Jiajia. (2019) "Research on the Demand of Smart Logistics Talents Based on the Construction of Hainan Free Trade Zone". Value Engineering, 38(6), pp. 1-3. (In Chinese).
[6] LI Xing. (2018) "Discussion on the Training Mode of Applied Logistics Talents under the Background of Intelligent Logistics Cainiaoyizhan". LOGISTICS ENGINEERING AND MANAGEMENT, 40(3), pp. 130132. (In Chinese). 